\title{
Parents' awareness and monitoring of teenage children's use of social media in Delta State, Nigeria
}

\author{
${ }^{1}$ Esharenana E. Adomi, Prof., ${ }^{2}$ Gloria O. Oyovwe-Tinuoye, $P h D$, and ${ }^{3}$ Jennifer N. B. Igwela, $P h D$ \\ ${ }^{1,2}$ Federal University of Petroleum Resources Library, Effurun, Delta State, Nigeria \\ ${ }^{3}$ Rivers State University Library, PMB 5080, Nkpolu-Oroworukwo, Port Harcourt. Nigeria \\ E-mail: ${ }^{1}$ esharenana.adomi@gmail.com, ${ }^{2}$ gloriatinuoye@yahoo.com, ${ }^{3}$ igwelaj@gmail.com \\ Cell: ${ }^{3}+2348063948870$
}

\begin{abstract}
The study examined parents' awareness of their teenage children use of social media in Delta State, Nigeria. Descriptive survey research design was adopted for the study using a self-constructed questionnaire as instrument of data collection. The questionnaire was constructed after extensive consultation of related literature in order to ensure that relevant items were included in it. The population of the study comprised of all parents in Delta State, Nigeria but the study adopted a purposive sampling technique to select respondents for the study. Data were collected through the use of a self-constructed questionnaire entitled "Parents' awareness of their teenage children use of the social media (PATCUSM)". The data collected were analysed using frequencies and simple percentages. The study has revealed that all parents' were aware that their teenage children used social media; a majority of them indicated that their teens used their mothers' device to access social media; teenagers use of Facebook attracted the highest responses followed by WhatsApp; a majority of the parents indicated that their teenage children access social media during the day, though most of them were not aware of the length of time their teens spent per visit to social media site; a majority of the respondents were aware that their teens used social media for academic matters and they monitored their teenage children. The study recommended that parents should ensure that they guide the children on fruitful use of social media to enhance their academic achievement and advancement; efforts should be made by parents to regularly monitor and supervise their teens children on social media in order to mitigate their use for antisocial purposes; parents should provide their teenage children with smart phones, but should monitor their use to ensure the teens use them for productive purposes.
\end{abstract}

Keywords: Parents' awareness, social media, teenage children' social media use, Delta State, Nigeria

\section{Introduction}

In the present era, the proliferations of information and communication technologies have made it easy for various categories of people, including teenagers, to have easy access to as well as use social media. Social media is a group of Internetbased applications that build on the ideological and technological foundations of Web 2.0, and that allows the creation and exchange of user-generated content (Kaplan \& Haelein,2010). According to Willett (2015), the use of social media among teenage children has been on the increase.Kanthawongsa and Kanthawongs (2013) asserted that there is increasing evidence that the amount of time teenage children are spending on social media at home and in school has raised concerns on the impact of these activities on their development.In orderfor teenagers to use social media effectively, parents' awareness and guidance is essential. Wang, Bianchi and Raley (2005) asserted that parental awareness of and involvement in their teenage children's internet use is paramount and given the risks, teens derive many benefits and gratifications from social media use.

Social media is an extension of their offline and face-to-face interactions of teenagers and it is a very important aspect of their social and creative lives. Social media is used by them to have fun, connect and maintain friendships, share interests, explore identities and cultivaterelationships with family; connect them to online global communities based on shared interests (Raising Children Network (Australia) Limited, 2020). Haythornthwaite (2005) stated that teenage children usually use social media without 
Esharenana E. Adomi, Gloria O. Oyovwe-Tinuoye and Jennifer N.B. Igwela: Parents' awareness and monitoring of teenage children's use of social media in Delta State, Nigeria

guidance or effective control, and this in turn reflects the challenges that have negative effects on their stability. Without protection under law for the consequence of teenage children's online activities, the responsibility of monitoring largely falls on parents (Costello \& Ramo, 2017). Henderson(2011) asserted thatmany parents buy computers and subscribe to get internet access in order to provide their teenage children with educationalresources. Similarly, El Khouli (2013) stressed that the necessity of the participation of parents in monitoring of the negative aspects of social media to teenage children is paramount.The participation of parents monitoring their teenage children's activities on social media is vital and parents' in Delta State should not be excluded.

Awareness of teenage children use of the social media by parents is necessary for our society of today. Badr, Alnuaimi, Rashedi, Yang and Temsah (2017) examined schoolchildren's use of digital devices, social media and parental knowledge and involvement in Abu Dhabi. Their finding revealed that about $82.2 \%$ of the respondents agreed that their parents were aware of their online social activities, followed by $12 \%$ of the respondents who were not sure of the parents awareness of their online social activities while $5.8 \%$ of the respondents said No. Liau, Khoo and Ang (2008) asserted that many parents are not aware of the full extent of their teenage children's online activities; mothers were found to be more aware of their adolescents' social media use than fathers. On the other hand, parents are ambivalent to the social media, as they are aware of the potential risks it carries by exposing users to negative content such as pornography, violence, commercialism, cyber bullying, unsupervised social relations, and privacy and security issues (Ceyhan, 2011).

Johansson and Gotestam (2004) noted that since the launching of Facebook in 2004, social media use has increased, especially among teenage children and adolescents.Lenhart, Purcell, Smith and Zickuhr (2010) stated that about $73 \%$ of American teenagers use social media and this rate is growing consistently over the last years.

In recent times, teenage children spent most of their time on social media.Researchers are now turning their attention to the large number of teenage children who have free access to the social media, and to the long hours they spend on it (Cho \& Cheon, 2005; Livingstone \& Bober, 2005). According to Lenhart and Madden (2007), about $93 \%$ of the teenagers in United States use the social media, more than three-quarters $(76 \%)$ have internet access at home, and about $63 \%$ go online every day. Similarly,Liau et al. (2008) stated that teenage children spend longer hours daily on social media than their parents, which parents are aware of, that they are exposed to some kind of online harassment.

Dorand Weimann-Saks (2013) asserted that the social media affords many opportunities for learning, entertainment; enrichment, and personal growth.Parents seem to be aware of such activities when the teenage childfirst engages in it. According to Liau et al. (2008), most parents whose teenagers have access to the internet claim that they share and/or support their teenage children on the social media, a claim not embraced by their teenage children. They further observed that most parents do not exercise significant supervision over their children's activity on the Web. Dor and WeimannSaks (2013) stated that parents should instruct their kids on safe conduct on the internet (e.g., "Don't give personal information to strangers"), and they assume that their children follow their instructions. However, surveys ofLenhart and Madden (2007) revealed that this is rare because teenage children often divulge personal information. In Abu Dhabi, the necessity of participation of families in the monitoring of these 
Esharenana E. Adomi, Gloria O. Oyovwe-Tinuoye and Jennifer N.B. Igwela: Parents' awareness and monitoring of teenage children's use of social media in Delta State, Nigeria

negative aspects of social networking for families is vital (El Khouli, 2013). Generally, parents are concerned about their teenage children's social, cognitive, and psychological development, and worry about possible effects such as increased aggression, antisocial behaviour, addiction problems, poor school performance, low self-esteem, and identity confusion (Cho \& Cheon, 2005; Fleming \& Rickwood, 2001; Lăzărescu, 2010; Wartella et al., 2002). Teenagers are those who are most likely to be guided by parents on the use of social media (Mesch, 2003). Teenage children seem to be much less concerned and anxious than their parents about possible future risks relating to social media (Livingstone, 2003).

Teenagers tend to feel more comfortable contacting strangers online, while parents are more concerned about the risks that might accompany it (Lim et al., 2003). According to American National School Boards Association (2007), teenagers lack key skills to evaluate properly online content and internet risks. Livingstone and Bober (2005) examined online activities of United Kingdom (UK) children. Their finding revealed that $18 \%$ of UK parents feel they lack the ability to help their child use the internet safely, and about $80 \%$ of them wish for stricter regulation of online services, and better information and advice for parents. It has been observed by Cho and Cheon (2005) that about $30 \%$ of the parents do not discuss the potential dangers of social media with their young ones. However, Dor and Weimann-Saks (2013) asserted that parents lack the necessary skills and knowledge, resulting in what can be interpreted as permissive behaviour.Wilson, Martins, and Marske (2005) examined children and parents' fright reactions to kidnapping stories in the news. Their finding revealed that teenage children's susceptibility to social media influence can vary according to their gender and age, and they conclude with guidelines to help parents enhance the positive effects of the social media while minimizing the risks associated with certain types of content.

Media plays a great role in shaping the ideas and beliefs of teenagers. Continuous access to and use of media has proven to influence a teenager's social, physical, and mental development. It can influence their mode of entertainment and self-expression, can be a source of inspiration, help to develop social skills, develop social and political awareness, assist to cultivate health habits, develop identity;associated with poor academic performance, sleep deprivation, reduced physical activity, and face-to-face social interaction which impact negatively on their health, etc. (Green \& Patwal, 2020). There are several influences attached to the use of social media by teenage children it could be positive or negative and such include; commercialism,sexting, cyberbullying, violence, harassment, entertainment, outing, impersonation, breaking into computers among others.Livingston and Bober (2004) investigated United Kingdom children who go online. Their finding revealed that the discrepancy between the large numbers of children who admit to being exposed to pornography, and a significantly smaller number of parents who are aware of their children's exposure to it. According to Ceyhan (2011), parents are ambivalent to the social media, as they are aware of the potential risks it carries by exposing uses to negative content such as pornography, violence, commercialism, cyber bullying, unsupervised social relations and privacy and security issues. Although, Kim (2007) and Lenhart (2005) opinion that negative effects of social media may impact the adult population as well but teenage children may be more susceptible.

Teenage children are the hope of future generation.It our duties to protect, nurture, guide and develop them to get a better society. In light of the foregoing, this study focused on parents' awareness of their teenage children use of social 
Esharenana E. Adomi, Gloria O. Oyovwe-Tinuoye and Jennifer N.B. Igwela: Parents' awareness and monitoring of teenage children's use of social media in Delta State, Nigeria

media Delta State, Nigeria. There have been several studies that focused on teenagechildren. However, none has explored parents' awareness and monitoring of their teenage children's use of social media use in Delta State, Nigeria. This study is intended to fill this research gap.

\section{Objectives of the study}

The study was intended to explore parents' awareness and monitorin of their teenage children's use of social media in Delta State, Nigeria. Specifically, the study set out to:

1. identify parents' awareness of their teenage children's use of social media;

2. find out parents' awareness of the social media the teenagers use;

3. reveal parents' awareness of the time of the day teenage children use social media;

4. unravel the parents' awareness of the reasons their teenage children's use social media;

5. find out the various ways parents monitor/supervise their teenage children's use of social media; and

6. explore the parents' awareness of the influence of social media on their teenagers.

\section{Methods}

The descriptive survey research design was adopted for the study while a self- constructed questionnaire was used as instrument data collection. The population of the study consisted of all parents in Delta State, Nigeria. However, purposive sampling technique was used to draw respondents for the study from six out of the twenty five local government areas of the state. This was because of COVID-19 movement restriction in the in 2019. (See Table 1 for the population and sample of the study).The questionnaire was administered face-to-face to parents in Delta State with the support of five research assistants who were trained on how to distribute the questionnaires to the respondents. Out of the 265 copies of the questionnaire distributed, 250 usable copies $(94.3 \%)$ were retrieved and used for the study. According to Richardson (2005), a response rate of $60 \%$ or more is desirable and adequate for survey research. Therefore, the response rate of $94.3 \%$ was considered very adequate for the study. The data collected were analysed using frequencies and percentages while the results are presented in tables.

\section{Results and discussion}

Table 1 reveals that the number of respondents by local governments. Uvwie Local Government Area had the highest number of respondents - 70(28\%). This was followed by Warri-SouthLocal Government Area $-46(18.4 \%)$.

Table 1: Number of respondents by Local Government Areas

\begin{tabular}{lll}
\hline Local Government Area & Freq. & Percentage \\
\hline Okpe & 44 & 17.6 \\
Sapele & 40 & 16 \\
Udu & 30 & 12 \\
Ughelli-South & 20 & 8.0 \\
Uvwie & 70 & 28 \\
Warri-South & 46 & 18.4 \\
Total & 250 & 100 \\
\hline
\end{tabular}

Table 2 reveals the occupations of the parents used in this study. Civil servant attracted the highest occupational group with $110(44 \%)$ respondents, followed by traders/ business man/ businesswoman- 
Esharenana E. Adomi, Gloria O. Oyovwe-Tinuoye and Jennifer N.B. Igwela: Parents' awareness and monitoring of teenage children's use of social media in Delta State, Nigeria

$89(35.6 \%)$. The table clearly reveals that the parents belong to various occupations.

Table 2: Occupations of the respondents

\begin{tabular}{lll}
\hline Occupations & Freq. & Percentage \\
\hline Civil servants & 110 & 44 \\
Traders & 89 & 35.6 \\
Company workers & 25 & 10 \\
Clergy & 11 & 4.4 \\
Technicians & 13 & 5.2 \\
Applicants & 2 & 0.8 \\
Total & 250 & 100 \\
\hline
\end{tabular}

Table 3: Marital status of respondents

\begin{tabular}{lll}
\hline Marital status & Freq. & Percentage \\
\hline Married & 220 & 88 \\
Divorced & 30 & 12 \\
\hline
\end{tabular}

Table 3 shows the demographic information of the parents in Delta State married followed by 30(12\%) who were by marital status. The table reveals thata divorced. majority of them $-220 \quad(88 \%)$-were

Table 4: Sex of respondents

\begin{tabular}{lll}
\hline Sex of respondents & Freq. & Percentage \\
\hline Male & 104 & 41.6 \\
Female & 146 & 58.4 \\
\hline
\end{tabular}

Table 4 reveals the sex of the respondents. The table reveals that a majority of them -

$104(41.6 \%)$ are female followed by $146(58.4 \%)$ were males.

Table 5: Number of teenage children owned by the respondents

\begin{tabular}{lll}
\hline Number of children & Freq. & Percentage \\
\hline One & 57 & 22.8 \\
Two & 94 & 37.6 \\
Three & 49 & 19.6 \\
Four & 35 & 14 \\
Five & 15 & 6 \\
Total & 250 & 100 \\
\hline
\end{tabular}

Table 5 shows number of teenage children owned by therespondents. A majority of the respondents had two children -
94(37.6\%) - followed by those with one child $-57(22.8 \%)$.

Table 6: Parents' awareness of the use of social media by their teenage children

\begin{tabular}{lll}
\hline Awareness & Freq, & Percentage \\
\hline Yes & 250 & $100 \%$ \\
No & - & - \\
\hline
\end{tabular}

An item in the questionnaire required the parents to indicate whether or not they were aware of their teens' use of social media. Table 6 reveals that all the 
Esharenana E. Adomi, Gloria O. Oyovwe-Tinuoye and Jennifer N.B. Igwela: Parents' awareness and monitoring of teenage children's use of social media in Delta State, Nigeria

respondents were aware that their teenage children usedsocial media. This implies that they had the experience that wouldenable them to respond to the questionnaire designed for the study.

Table 7: Ownership of devices teenage children use to access/use social media

\begin{tabular}{lll}
\hline Ownership of device & Freq. & Percentage \\
\hline Owned by mother & 120 & 48 \\
Owned by brothers/sisters & 72 & 28.8 \\
Owned by father & 62 & 24.8 \\
Owned by my teenage child(ren) & 49 & 19.6 \\
Owned by relatives & 41 & 16.4 \\
Owned by friends/classmates & 38 & 15.2 \\
\hline
\end{tabular}

Table 7 reveals ownership of devices teenage children use to access/use social media. The gadget owned by mothers attracted highest responses of $120(48 \%)$ while owned by fathers came third with 62 (24.8\%). Teens tend to be closer to and most likely share their problems with their mothers than fathers as revealed in a study by $\mathrm{Yu}$ and Baxter (2018). This must have accounted for why the teens in this current study used their mothers' smart phones more than their fathers' to access social media.

A total of $49(19.6 \%)$ of the teens used their personal smart phones.
Smartphone ownership has expanded and dramatically increased among teenagers over the past six years (McClellan, 2018). Uzuegbunam (2020) found in his survey that an increasing number of Nigerian teenagers have access to digital technologies, especially mobile phones and the mobile internet; that two-thirds $(63.7 \%)$ of mostly 14 to 18 year olds in semi-urban and urban settings owned mobile phones of their own, while others had access to a shared smartphone or a simple feature phone through their siblings and friends.

Table 8: Awareness of the social media used by teenage children

\begin{tabular}{lll}
\hline Awareness of social media used & Freq. & Percentage \\
\hline Facebook & 120 & 48 \\
WhatsApp & 90 & 36 \\
Instagram & 80 & 32 \\
YouTube & 45 & 18 \\
Twitter & 37 & 14.8 \\
Snapchat & 10 & 4.0 \\
\hline
\end{tabular}

Table 8 focuses on parents' awareness of the social media used by their teenage children. Facebook attracted the highest responses $-120(48 \%)$ followed by WhatsApp $90(36 \%)$ and Instagram $80(32 \%)$. This is in accordance with Johansson and Gotestam(2004) who reported that since the launching of Facebook in 2004, internet use has increased, especially among teenage children and adolescents. The result reported in Table 8 are at variance with that by Clement (2020) who reported in his study that themost important social network recorded 44 percent of United States teenagers during the fall 2019 survey wasSnapchat while fast-growing social video app TikTok was ranked third with $4 \%$ of teenagers in the United States stating it to be their favorite, ahead of legacy social network platforms Facebook and Twitter. 
Esharenana E. Adomi, Gloria O. Oyovwe-Tinuoye and Jennifer N.B. Igwela: Parents' awareness and monitoring of teenage children's use of social media in Delta State, Nigeria

Table 9: Time of the day teenage children use social media

\begin{tabular}{lll}
\hline Time of the day & Freq. & Percentage \\
\hline During the day & 160 & 64 \\
At night & 55 & 22 \\
Early morning & 35 & 14 \\
\hline
\end{tabular}

Table 9 shows time of the day spent on social media by their teenage children. During the day attracted the highest responses of $160(64 \%)$ followed by $55(22 \%)$ while early morningattracted the lowest response rate $-35(14 \%)$.It has been reported by Hutchinson (2018) that parents underrate how much their teens are checking their phones in the morning. That could mean that they do not even know exactly how active their teens areaccessing social media.

Table 10: Awareness of duration/length of time teenage children spend per visit to social media sites

\begin{tabular}{lll}
\hline $\begin{array}{l}\text { Duration/length of } \\
\text { time }\end{array}$ & Freq. & $\%$ \\
\hline I don't know how long & 109 & 43.6 \\
1-2hours & 81 & 32.4 \\
Less than 30 minutes & 35 & 14 \\
2hours and above & 25 & 10 \\
\hline
\end{tabular}

Table 10 reveals awareness of the duration/length of time teenage children spend per visit to social media site.The majority 109(43.6\%) donot know the length of time their spent on social media.

This could due to the fact that teenagers are not with their parents most of the time - parents spend most of their time at work day time in school. Also, most teenagers do not share the living room with their parents. These factors would therefore make it difficult for the parents to be aware of the length of time their teenage children spend using social media. This finding corroborates the report by Hutchinson (2018) that parents in United States do not even know exactly how active their teens are online.

Table 11: Awareness of the reasons the teenage children use social media

\begin{tabular}{lll}
\hline Reasons the teenage children use social media & Freq. & Percentage \\
\hline Academic purpose & 120 & 48 \\
Interaction with friends & 98 & 39.2 \\
Plan events & 73 & 29.2 \\
To keep in touch with friends & 68 & 27.2 \\
Communicate with class mates & 61 & 24.4 \\
Share photos & 58 & 23.2 \\
Scholarship opportunities & 50 & 20 \\
Career information & 48 & 19.2 \\
Browse current news & 38 & 15.2 \\
Food varieties/nutrition & 35 & 14 \\
Communicate with teachers & 25 & 10 \\
Clothing style/fashion & 24 & 9.6 \\
Hairstyles & 13 & 5.2 \\
\hline
\end{tabular}


Esharenana E. Adomi, Gloria O. Oyovwe-Tinuoye and Jennifer N.B. Igwela: Parents' awareness and monitoring of teenage children's use of social media in Delta State, Nigeria

Table 11 focuses on reasons teenage children use social media. Though it has been noted that it could be difficult for a parent to understand the reasons his/her teenager uses social media so much (Reach Out Australia, 2020), the parents in this study are aware why their teenage children use it. Academic purposes attracted the highest number of respondents-120(48\%).

Teenage Students learn in various new ways using social media (Tartari, 2015). They can obtain information that will enrich what they have been taught in school from social media. It could be seen from the tablethat amajority of the teenagers use the social media for academic matters. Weimann-Saks (2013) have accordingly noted that social media affords many opportunities for learning, entertainment,enrichment and personal growth.

Table 12: Ways parents monitor/supervise teenage children's use of social media

\begin{tabular}{lll}
\hline Ways parents monitor/supervise teens' use of social media & Freq. & Percentage \\
\hline I monitor my teenager chats & 109 & 43.6 \\
I advise my teenager not to give out personal information on & 88 & 35.2 \\
social media & 64 & 25.6 \\
Prohibit/restrict site & 58 & 23.2 \\
I monitor my teenager's social media account by logging into & & \\
it. & 41 & 16.4 \\
Prescribe the use time/time to use the social media & 29 & 11.6 \\
Recommend social media/platform to use & 25 & 10 \\
I monitor the number of friends/contacts my teenager have on & & \\
social media. & 23 & 9.2 \\
I regularly watch what my teenager does on social media & 20 & 8.0 \\
I add my teenagers as friend on social media & 19 & 7.6 \\
I teach my teenager how to act properly online & 18 & 7.2 \\
Co-use /use with them &
\end{tabular}

Table 12 reveals ways the parents monitor and supervise their teens' use of social media. Parents are generally the primary gatekeepers and managers of their teens' social media experience. They give advice and influence their teens' understanding of proper and improper digital behavior as well as keep them safe online and offline by employing various control measures (Lenhart, Madden, Smith, Purcell \& Zicku hr, 2011). Monitoring of teenager chatshas the highest number of respondents -109 $(43.6 \%)$. This is to ensure online safety of the child. Advising the teenager not to give out personal information on social media ranked second with $88(35.2 \%)$ respondents. This corroborates Dor and Weimann-Saks (2013) advice that parents should instruct their kids on safe conduct on social media. 
Esharenana E. Adomi, Gloria O. Oyovwe-Tinuoye and Jennifer N.B. Igwela: Parents' awareness and monitoring of teenage children's use of social media in Delta State, Nigeria

Table 13: Awareness of influence of social media on teenage children

\begin{tabular}{lll}
\hline $\begin{array}{l}\text { Awareness of influence of social media on teenage children } \\
\text { use of social media }\end{array}$ & Freq. & Percentage \\
\hline Assist them to access academic information. & 183 & 73.2 \\
Keep them abreast recent/ current development & 102 & 40.8 \\
Enable teenager to be sociable & 66 & 26.4 \\
Eradicate loneliness & 43 & 17.2 \\
Ease of connections with friends/relatives. & 35 & 14 \\
Cyberbullying & 30 & 12 \\
Exposure to pornography & 23 & 9.2 \\
Poor/low school performance & 18 & 7.2 \\
Addiction to social media & 15 & 6.0 \\
Arouses crises /confusion & 13 & 5.2 \\
Emotional /mental problems & 12 & 4.8 \\
Violence & 10 & 4.0 \\
Divulgence/leakages of personal information & 09 & 3.6 \\
\hline
\end{tabular}

Table 13 focuses on awareness of the influences of social media on teenage children. Parents have been reported to be concerned about the influence of social media on teenage children's healthy habits and pursuits (Ann \& Robert H. Lurie Children's Hospital of Chicago, 2020). Assist them to access academic information attracted the highest responses - 183(73.2\%) followed byto keep them abreast of recent/current development 102(40.8\%) while violence, emotional/mental problems and divulgence/leakage of personal information has the lowest response rate. It could be seen thatamajority of the teenagers use social media for academic information. Exposure to pornography attached 23(9.2\%). Livingston and Bober (2004) had earlier repotted that a large number of teenage children admitted to being exposed to pornography on social media buta smaller number of parents are aware of their teenagechildren's exposure to it.

\section{Conclusion}

The study focused on parental awareness and control of their teenage children's use of social media in Delta State, Nigeria.The studyhas revealed that all parents' were aware that their teenage children used social media; a majority ofthem indicated that that their teensused their mothers' device to access social media; teenagers use of Facebook attracted the highest responses followed by WhatsApp; a majority of the parents indicated that their teenage children access social media during the day, though most of them were not aware of thelength of time their teens spend per visit to social media site; a majority of the respondents were aware that their teens used social media for academic matters and they monitoredtheir.

Based on the findings, the following are recommended:

1. Parents should ensure that they guide the children on fruitful use of social especially to enhance their academic achievement and advancement.

2. Efforts should be made by parents to regularly monitore and supervises their teens on social media in order to mitigate their use for antisocial purposes.

3. The Parent should provide their teenage children with smart phones, but should monitor their use should be to ensure their online safety and productive use. 
Esharenana E. Adomi, Gloria O. Oyovwe-Tinuoye and Jennifer N.B. Igwela: Parents' awareness and monitoring of teenage children's use of social media in Delta State, Nigeria

\section{References}

American National School Boards Foundation (2007). Creating and connecting: Research and guidelines on online social and educational networking. Retrieved from https://grunwald.com/pdfs/Gru nwaldNSBAStudy_Kids_Social_Med ia.pdf.

Ann and Robert H. Lurie Children's Hospital of Chicag(2020). Parenting teens in the age of Social media. Retrieved from https://www.luriechildrens.org/en/b $\log$ /social-media-parentingstatistics/.

Badr, A., Alnuaimi, A., Rashedi, A., Yang, G. \& Temsah, K. (2017). Social children's use of digital devices social media and parental knowledge and involvement:The case of Abu Dhabi. Education Information Technologies, 22, 264 5-2664.

Ceyhan, A. A. (2011). University students' problematic internet use and communi ca ti on skills according to the internet use purposes. Educational Sciences: Theoryand Practice, 11(1), 69-77.

Cities of Peace, Inc. (n.d.). Warri, Nigeria: City of peace. Retrieved from http://www.internationalc ities of peace.org/cities-listing/warri-nige ria.

Costello, C. R. \& Ramo, D. E. (2017).What should we be recommending to teens and their parents. Journal of Adolescent Health, 60,629-630.

Cho, C. \& Cheon, H. J. (2005). Children's exposure to negative internet content: Effects of family context. Journal of Broadcasting and Electronic Media, 49(4), 488-509.

Clement, J. (2020). Favorite social networks of U.S. teens 2012-2019. Retrieved from https://www.statista.com/statistics/ 250172/social-network-usage-ofus-teens-and-young-adults/.
Dor, A. \& Weimann-Saks, D. (2013). Children's Facebook usage parental awareness, attitu des and behaviour. Studies on Media Communication, 1(1).1-13.

El Khouli. M. (2013).The most important negative aspects of using networking affecting the family stability in Abu-Dhabi a pilot study. IACSIT International Journal of Engineering and Technology, 5(1), 85-99.

Fleming, M. J. and Rickwood, D. J. (2001). Effects of violent versus non-violent video

games on children's arousal aggressive mood and positive mood. Journal of Applied Social Psychology, 31, 2041-2071.

Green, T. and Patwal, S. (2020). 13 positive and negative influences of media on teenagers. Retrieved from https://www.Momjunction.com/art icles/positive-and-negative-influen ces-of-media-on-teenagers0010797 $5 /$.

Haythornthwaite, C. (2005). Social networks and internet connectivity effects. Journal of Information, Communication, and Society, 8(2), 125-147.

Henderson, R. (2011).Classroom Pedagogies digital literacy's and home school digital divine. International Journals of Pedagogies Learning, 6(2), 152161.

Hutchinson, A. (2018). New study finds teens and parents are concerned about excessive

socialmedia usage. Retrieved from https://www.socialmediatoday.com /news/new-study-finds-teens-andparents-are-concerned-aboutexcessive-social-medi/530837/.

Johansson, A. \& Gotestam, K. G.(2004). Internet addiction: Chara cteristics of a questionnaire a nd prevalence in Norwegian Youth (12-18years). 
Esharenana E. Adomi, Gloria O. Oyovwe-Tinuoye and Jennifer N.B. Igwela: Parents' awareness and monitoring of teenage children's use of social media in Delta State, Nigeria

Scandinavian Journ al of Psychology, 45,223-229.

Kaplan, A. M. \& Haelein, M. (2010).Users of the World,unite! The challenges and opportunities of social media.Bu siness Horizons, 53(1), 59-68.

Kanthawongsa, P. \& Kanthawongs, P. (2013). Perception of primary school students,

parents and teachers toward the use of computers, the internet and social networking sites. Procedia Social and Behavioral Sciences, 88, 282-290.

Lăzărescu, M. P. (2010). Considerations on the impact of television and internet addiction recovery method for college students in Korea. International Journal of Reality Therapy, 26(2-3), 3-9.

Lenhart, A. (2005). Protecting teens online Washington DC: Pew internet and American lifeproject. Retrieved from http://.www.pewinternet.org.

Lenhart, A., Madden, M., Smith, A. Purcell, K. \& Zickuhr, K. (2011). Teens, kindness and cruelty on social network sites: Part 4:The role of parents in digital safekeeping and advice-giving. Retrieved from https://www.pew research.org/internet/2011/11/09/pa rt-4-the-role-of-parents-in-digitalsafekeeping-and-advice-giving/.

Lenhart, A., Purcell, K., Smith, A. \& Zickuhr, K. (2010). Social media and mobile internet use among teens and young adults. Retrieved from http://.pewinternet.org.//med ia/files/report/2010/pip/socialmedia andyoungadultsreportfinalwithpho nes.pdf.

Lenhart, A. \& Madden, M .(2007). Social networking websites and teens.Pew internet and American Project. Retrieved from http://www.pewinternet.org/m e d i a / files/reports/2007.
Liau, A. Khoo, A. \& Ang, P. (2008) Factors influencing adolescents engagement in risking Internet behaviour. International Journal of Cyber Behaviour Psychology, 8(2), 513-520.

Lim , C. P., Khoo, A. and Wiiliams, M. D.(2003). A comparism of Singapore parents and childrens' use of the internet and perceptions of itdangers. Journals of ASPEC Studies, 5(1), 85-103.

Livingstone, S. (2003). Children's use of the internet: Reflections on the emerging research agenda .New Media and Society, 5(2),147-166.

Livingstone, D. \& Bober, R. (2004). What anyone can know: the privacy risk of social networkingsites. Retrieved http://w ww.computer.Org/portal/web/csdl/ doi/10.1109/M.

Kim, J. U. ( (2007). A reality therapy group program as an internet addiction recovery method for college students in Korea.International Journalof Reality Therapy, 26(2-3), 3-9.

McClellan, J. (2018). Teen study: 89 percent have Smartphone's; hate content exposure has gone up. Retrieved from https://www.usato day.com/story/life/allthemoms/201 8/09/10/teens-say-social-medi ahas-positive-effect-how-they-fe elcommon-sense-media/1204457 002/.

Mesch, G.S. (2003). The family and the internet: The Israeli case. Social Science Quarterly,84(4),103-105.

Raising Children Network (Australia) Limited. (2020). Social media benefits and risks:Children and teenagers. Retrieved from:https:// raisingchildren.net.au/teens/entertai nment-.

Tartari, E. (2015). Benefitsand risks of children and adolescents using social media. European Scientific Journal, 11(13). Retrieved from 
Esharenana E. Adomi, Gloria O. Oyovwe-Tinuoye and Jennifer N.B. Igwela: Parents' awareness and monitoring of teenage children's use of social media in Delta State, Nigeria

file://C:/Users/UL/App Data

Local/Temp/5654-Article\% 20Text -16524-1-10-20150530.pdf.

Uzuegbunam, C. (2020). Why it's time for adults to accept that Nigerian teenagers have a digital life. Retrieved from https://theconv ersation.com/why-its-time-for-adul ts-to-accept-that-nigerian-teenage rs-have-a-digital-life-139498.

Wang, R., Bianchi, S. \& Raley, S. (2005). Teenagers internet use and family rules a research note .Journals of Marriage and Family 67,12491258.

Wartella, E., Lee, J. H. \& Caplovitz, A. G.(2002). Children and interactive media: An updated research compendIumMIracleFoundation. Retrieved from http://.www.digit al.kids-net/modules/php.

Willett, R. (2015). Thediscursive construction of good parenting and digital media. The case of children's virtualworldgames. Med ia, Culture and Society,37(7), 10601075.

Wilson, B., Martins, N. and Marske, A. (2005). Children's and parent's fright reactions to kidnapping stories in the news. Communication Monographs,72(1 ),46-70.

Yu, M. \& Baxter, J. (2018). Relationships between parents and young teens. Retrieved from https://growingupinaustralia.gov.au /research-findings/annualstatisticalreport-2017/relationships-between -parents-and-young-teens. 